\title{
UPAYA MENINGKATKAN KEMAMPUAN SENSORIK AUDI MELALUI APE PLAY DOUGH DAN BONEKA SARUNG TANGAN DESA POHJEJER
}

\author{
Luqmanul Hakim ${ }^{1)}$ Aden Wahyu Wijanarko ${ }^{2)}$, Fadhilah Elvina ${ }^{3)}$ Samilatus Sa'adah ${ }^{4}$, \\ 1,2,3 Fakultas Keguruan dan Ilmu Pendidikan, Universitas PGRI Adi Buana Surabaya. \\ ${ }^{4}$ Fakultas Ekonomi, Universitas PGRI Adi Buana Surabaya. \\ Email : luqmanulhakim@unipasby.ac.id,elvinaelena66@gmail.com
}

\begin{abstract}
Abstrak
Educational Game Equipment (APE) adalah alat permainan yang dirancang khusus untuk tujuan pendidikan, Mayke dan APE adalah salah satu program yang diminati penduduk desa Pohjejer. Kegiatan program ini terdiri dari dua bagian: Play Dough dan Puppet Gloves. Implementasi 2 bagian divisi APE dilakukan secara terpisah dengan mempertimbangkan target lima divisi yang berbeda. Pengamatan yang yang dilakukan adalah proses pengamatan dan pencatatan secara sistematis / berurutan, logis, obyektif dan rasional, baik dalam situasi aktual maupun dalam situasi artifisial untuk mencapai tujuan tertentu. Metode yang digunakan adalah observasi untuk mengetahui tingkat apresiasi PKK, guru dan anak TK / pohjejer. Hasil yang dicapai dari kegiatan ini adalah . guru playgroup dan guru TK berjalan dengan baik dan lancar dengan antusias yang tinggi.
\end{abstract}

Kata Kunci: APE, Bermain Adonan, Desa Pohjejer

\begin{abstract}
Educational Game Equipment (APE) is a game tool designed purposely for educational purposes, Mayke and APE is one of the programs that Pohjejer villagers are interested in. The program activities consist of two parts: Play Dough and Puppet Gloves. The implementation of 2 parts of the APE division is done separately considering the target of five different divisions. Zainal observation is the process of observation and recording systematically / sequentially, logically, objectively and rationally, both in actual situations and in artificial situations to achieve certain goals. The method used is the observation to determine the level of appreciation PKK, teachers and children kindergarten / early childhood village pohjejer. The results achieved from this activity are. Playgroup teachers and kindergarten teachers went well and smoothly with high enthusiasm.
\end{abstract}

Keywords: APE, Play dough, Pohjejer Village

\section{PENDAhUluaN}

Undang- Undang RI Nomor, 20 Tahun 2003 tentang sistem pendidikan nasional Bab 1 Ayat 14 menyatakan "pendidikan anak usia dini adalah upaya pembinaan yang tujukan kepada anak sejak anak lahir sampai dengan usia enam tahun yang dilakukan melalui pemberian rangsangan pendidikan untuk membantu pertumbuhan dan perkembangan jasmani dan rohani agar anak memiliki kesiapan memasuki pendidikan lebih lanjut".

Sebagai salah satu divisi yang memegang peranan dalam mendidik anak usia dini pada suatu kelompok besar pengabdian masyarakat. Kami dituntut untuk dapat mengekspos segala bentuk potensi desa kkn kami yaitu, pohjejer. Desa pohjejer sendiri terbagi menjadi enam dusun yaitu Dusun pohjejer, Dusun juwetrejo, Dusun jeruk, Dusun telagan, Dusun turi, dan Dusun ngayuman. Anak usia dini memiliki kemampuan belajar yang luar biasa terutama pada masa kanak-kanak. Keingintahuan anak untuk belajar menjadikan anak kreatif dan eksploratif. Anak belajar dengan seluruh panca inderanya untuk memahami sesuatu dan dalam waktu yang singkat beralih ke hal lain untuk dipelajari. Karakteristik anak usia 
dini menjadi hal yang penting untuk dipahami agar memiliki generasi yang mampu mengembangkan diri secara optimal mengingat pentingnya usia emas (the golden age) tersebut.

Mengembangkan kreativitas anak memerlukan peran penting pendidik. Anak kreatif memuaskan rasa keingintahuannya melalui berbagai cara seperti bereksplorasi, bereksperimen, dan banyak mengajukan pertanyaan kepada 2 orang lain. Namun kenyataannya masih banyak anak-anak yang memiliki kreativitas yang rendah. Keadaan tersebut disebabkan karena kurangnya pengembangan kreativitas sejak usia dini. Kegiatan pembelajaran di TK dan PAUD desa pohjejer, cenderung pada kegiatan mewarnai dan bernyanyi. Hal ini menyebabkan anak bosan dan cenderung bermain sendiri ketika kegiatan pembelajaran. Berdasarkan permasalahan tersebut, dapat memberikan pembelajaran yang berbeda dari kegiatan sebelumnya yaitu Play Dough dan sarung tangan.

Play Dough adalah adonan mainan yang terbuat dari tepung terigu.Permain Play Dough, dapat bermanfaat dalam perkembangan berfikir anak kemampuan sensorik (belajar tentang tekstur dan menciptakan sesuatu), dan kemampuan sosial anak. Menurut Yuliani (2012) bahwa "Pemberian rangsangan melalui pendidikan anak usia dini perlu diberikan secara komprehensif, dalam makna anak tidak hanya dicerdaskan otaknya, akan tetapi cerdas pada aspek-aspek lain dalam kehidupannya. Begitu juga menurut Anik (2007) menyatakan dengan menggunakan permainan sejenis tanah liat, anak dapat membuat berbagai macam bentuk yang disukai anak.

Kreatif dan inovatif merupakan dambaan setiap orang tua terhadap anaknya. Namun, sangat jarang anak-anak zaman sekarang melakukan hal-hal positif yang berhubungan dengan ide atau gagasan mereka. Banyak anak-anak yang lebih tertarik dengan permainan modern karena beberapa bahannya mengandung zat-zat berbahaya, selain itu anak-anak bermain dengan gadget yang kurang mendidik sehingga membuat minat belajar menjadi turun.

APE adalah salah satu program yang diminati dan mendapat perhatian dari warga desa Pohjejer. Untuk kegiatan program APE tediri dari 2 bagian yaitu Play Dough dan Boneka Sarung Tangan. Pelaksanaan 2 bagian dari divisi APE dilakukan secara bersamaan dibalai desa pohjejer. Untuk Play Dough dan sarung tangan, targetnya adalah guru-guru Playgroup dan TK. Pelaksanaan program tersebut dilaksanakan pada hari selasa tanggal 24 Februari 2019. Untuk pelaksanaannya, anggota mahasiswa divisi APE dibantu anggota divisi yang lain, mengajak para guru PAUD dan guru TK untuk praktek dan belajar menggunakan media Play Dough dan boneka sarung tangan, sebagai bahan ajar untuk mengajar siswa-siswi dari sekolah masing-masing. Untuk Play Dough, mahasiswa dari divisi APE memberikan pengarahan secara langsung.

Pertama, memberikan pengarahan terlebih dahulu dengan langsung mempraktikkan cara membuat play dough. Kemudian yang kedua, untuk sarung tangan, para guru diarahkan dan diajarkan untuk membuat berbagai macam bentuk boneka dari sarung tangan. Para Ibu PKK menaruh perhatian yang besar dan antusias dalam mengikuti pengarahan yang diberikan oleh perwakilan divisi APE. Oleh karena itu, mahasiswa membuat alternatif permainan yang mendidik bagi anak-anak di Desa pohjejer yaitu, Program APE.

Program APE adalah program pembuatan Alat Permainan Edukatif untuk membangun dan mengembangkan jiwa kreatif anak anak, remaja, serta ibu-ibu di desa pohjejer, kecamatan Gondang, Mojokerto. Program ini berupa Permainan seperti Boneka Sarung Tangan. Yang dapat diaplikasikan dalam kehidupan sehari-hari anak-anak dan alat permainan yang aman karena bahan yang digunakan tidak berbahaya selain itu ramah lingkungan. Tujuannya adalah Melatih masyarakat sekitar dalam menumbuh kembangkan kreatifitas 
dengan membuat keterampilan dengan bahan yang mudah didapat dan harga terjangkau.

\section{METODE PELAKSANAAN}

\section{a. Pelaksanaan kegiatan kepada perangkat}

Pelaksanaan kegiatan dilakukan dibalai desa Pohjejer yang diikuti oleh semua guru KB dan TK yang ada di desa Pohjejer yang berjumlah 17 guru,yang dilaksanakan pada tanggal 13 Februari 2018 pada pukul $10.00 \mathrm{~s} / \mathrm{d} 12.00$ WIB. Para guru TK sangat antusias mengikuti arahan yang diberikan oleh mahasiswa. dengan tujuan dapat mempraktekkan kembali untuk permainan siswa-siswi di Playgoup dan TK

\section{b. Metode}

Menurut Riduwan (2004) menyatakan bahwa observasi adalah merupakan teknik pengumpulan data, dimana peneliti melakukan pengamatan secara langsung ke objek penelitian untuk melihat dari dekat kegiatan yang dilakukan

Sedangkan menurut Kartono (2011) observasi adalah pengujian dengan maksud atau tujuan tertentu mengenai sesuatu, khususnya dengan tujuan mengumpulkan fakta, satu skor atau nilai, satu verbalisasi atau pengungkapan kata-kata segala sesuatu yang telah diamati. Metode yang digunakan observasi untuk mengetahui tingkat apresiasi guru-guru TK/PAUD di desa Pohjejer.

\section{HASIL DAN PEMBAHASAN}

Kegiatan Program APE dilaksanakan pada tanggal 24 Februari 2019. Target peserta dalam program adalah 17 peserta. Sumber dana yang digunakan berasal dari LPPM dan Iuran Mahasiswa Pengabdi. Adapun rincian rencana dan jadwal kegiatan sebagai berikut:

Penelitian ini bertujuan untuk melihat peningkatan media playdough dan boneka sarung tangan dalam meningkatkan kemampuan sensorik dan kreativitas anak usia dini/TK khususnya pada guru playgroup yang sebagai sarana belajar siswa. Data yang diperoleh dari penelitian yang dilakukan merupakan hasil tingkat kreativitas guru yang diukur melalu observasi. Pemberian seminar APE pada masyarakat POH JEJER diharapkan dapat membantu menumbuh kembangkan kretaifitas anak dalam berpikir dan mampu meningkatkan kemampuan sensorik anak.

Media playdough dan boneka sarung tangan ini membuat anak suka berkreasi sehingga dapat mengembangkan kreativitasnya dan kemampuan sensorik. Anak dilatih untuk menggunakan imajinasi untuk menciptakan suatu bangunan dan menumbuhkan imajinasi dalam suatu karangan cerita yang diceritakan oleh guru. Hal ini menunjukkan bahwa media tersebut merupakan salah satu stimulus yang tepat dalam mengoptimalkan perkembangan kreativitas anak.

Kondisi awal sebelum menggunakan playdough yaitu ada salah satu warga atau orang tua yang mengalami kesulitan dalam memberikan pengajaran kepada anak, kesulitan yang dialami oleh anak tersebut adalah tingkat kreativitasnya rendah sekali, anak tersebut memiliki karakter yang pendiam dan dalam kondisi belajarnya siswa kurang aktif karena rasa malu yang dimilikinya. Guru sebagai pengajar pada sekolah setempat juga mengeluhkan hal yang sama, kesulitan yang dialami dalam menumbuh kembangkan kreativitas anak agar memiliki keterampilan sensorik juga merasakan kesulitan karena keterhambatan biaya dalam memenuhi kebutuhan sarana prasarana seperti media pembelajaran, dan lain sebagainya.

Kondisi akhir setelah orang tua dan guru mengetahui cara pembuatan dan penggunaan permainan playdough dan boneka sarung tangan didapat bahwa terdapat peningkatan kreativitas guru dan orang tua anak dalam memberikan pembelajaran yang lebih menarik, kreatif, dan inovatif dengan menggunakan bahan bekas dan bahan rumah tangga yang dapat menumbuh kembangkan cara belajar siswa dan menumbuhkan 
keterampilan sensorik anak dalam belajarnya. Hasil peneitian Play dough dan boneka sarung tangan yang dilakukan kepada guru playgoup dan guru TK di desa pohjejer kecamatan Gondang kabupaten Mojokerto, Pembekalan untuk menumbuhkan kreatifitas guru PAUD dilaksanakan sangat antusias dengan mengikuti langkah-langkah pembuatan, sehingga proses berjalan dengan lancar. peserta dari pelatihan pembuatan APE ini sangat antusias, banyak anak-anak yang gembira ketika diajak bermain playdough Sehingga APE dengan media playdough dan boneka sarung tangan bisa menambah wawasan dan kreatifitas anak-anak, para orang tua, dan guru yang terlibat didalamnya dan terdapat peningkatan kemampuan sensorik dan kreativitas pada anak usia dini sebelum dan setelah menggunakan media playdough dan boneka sarung tangan.

\section{KESIMPULAN}

Pembelajaran pada anak usia dini dengan menggunakan media playdough dapat meningkatkan kreativitas anak. Anak usia dini lebih senang belajar sambil bermain dengan menggunakan media playdough yang memberikan kebebasan pada anak untuk berkreatif. Program kerja pokok APE dalam pembuatan play dough dan boneka sarung tangan yang dilaksanakan dibalai desa POhjejer pada tanggal 13 Februari 2019 pada jam 08.00-12.00 dengan sasaran guru playgroup dan guru TK berjalan dengan baik dan lancar dengan antusias yang tinggi.

\section{REFERENSI}

Anik, P. 2007. Mengembangkan kreativitas dan kecerdasan anak. Jakarta: Buku kita.

Kartono, K. 2011. Kamus Lengkap Psikologi J.P.Chaplin.Jakarta : Rajawali Pers.

Martuti, A. 2008. Mengelola PAUD dengan Aneka Permainan Meraih Kecerdasan Majemuk. Yogyakarta: Kreasi Wacana.

Riduwan. 2004. metode Riset. Jakarta: Rineka Cipta.
Undang-undang Republik Indonesia. (2003). Nomor 20 Tahun 2003 Tentang Sistem Pendidikan Nasional. Jakarta: Depdiknas.

Yuliani, N.S. 2012. Konsep Dasar Pendidikan Anak Usia Dini, Jakarta: PT Indeks 